\title{
To deconstruct or how to deconstruct?: A Presbyterian perspective, 1960-1990
}

\begin{abstract}
Author:
Graham A. Duncan ${ }^{1} \mathbb{C}$

Affiliation:

${ }^{1}$ Faculty of Theology,

Department of Church History and Church Polity,

University of Pretoria,

South Africa

Research Project Registration: Project Leader: G.A. Duncan Project Number: 02618958

\section{Description}

This research is part of the research project, 'History of Theological Education in Africa' directed by Prof. Dr Graham Duncan of the Department of Church History and Church Polity at the Faculty of Theology, University of Pretoria.
\end{abstract}

Corresponding author: Graham Duncan, graham.duncan@up.ac.za

Dates:

Received: 18 Apr. 2017

Accepted: 05 Aug. 2017

Published: 29 Nov. 2017

How to cite this article: Duncan, G.A., 2017, 'To deconstruct or how to deconstruct?: A Presbyterian perspective, 1960-1990', HTS Teologiese Studies/ Theological Studies 73(1), a4595. https://doi.org/ 10.4102/hts.v73i1.4595

\section{Copyright:}

(c) 2017. The Authors. Licensee: AOSIS. This work is licensed under the Creative Commons Attribution License.

Read online:

Scan this $Q R$ code with your smart phone or mobile device to read online.
The art of deconstruction is a process that aims to lead to the truth; the truth regarding apartheid in South Africa is contested. Presbyterian historiography regarding apartheid has lacked clarity because of a lack of reliable sources. This article seeks to elucidate greater clarity by interrogating one source written from within the Presbyterian Church of Southern Africa dealing with the period, 1960-1990.

\section{Introduction}

The art of deconstruction is a process that aims to lead to the truth, but we may ask what kind of truth and whose truth? A blurred sepia-tinged photograph shows the truth of an image but then so does a high-definition photograph. The general truth remains the same but the detail is very different. Then there is the matter of what hermeneutical lens we apply to our interpretation of the representation so the issue becomes a question of whose truth, what kind of truth and what level of truth? One detail or the quality of an image may assume far greater importance for an interpreter than another. Jack Thomson (2012) has demonstrated this in his insightful book about mission photography. When we come to an issue such as the emotive matter of apartheid, we enter even more contested territory. And for the Presbyterians, this becomes an even greater problem because of the dearth of appropriate resources. The late Professor Calvin Cook, Professor of Ecclesiastical History at Rhodes University, gave up the task of writing a history of the Presbyterian Church of Southern Africa (PCSA) because of a lack of relevant resources to write a comprehensive history and support, and then his eyesight failed him. The Rev Douglas Bax produced a pocket history of the PCSA in 1997. To date, only a few articles by the author have picked up aspects of this history with a specific focus on racism and only recently the author was commissioned by the Uniting Presbyterian Church in Southern Africa (UPCSA) to prepare a history of the UPCSA, formed in 1999 through the union of the PCSA and the Bantu Presbyterian Church of South Africa/Reformed Presbyterian Church in Southern Africa (BPCSA/RPCSA).

This article stands as a testimony and challenge to the deconstruction of Presbyterianism and its attitude towards apartheid. I shall deal with one source prepared by Rev Douglas Bax: a paper he presented at a conference at Stellenbosch University in 2012 published as: 'The Struggle for Justice between 1960 and 1990 and the Witness of the Presbyterian Church of Southern Africa' (2013:143170). Let it be said at this point that Bax is not a historian but a minister of the UPCSA with a strong interest in matters theological and matters related to social justice. This latter concern is not common in the history of the PCSA. Bax is virtually the only minister in the apartheid PCSA who had the stamina and commitment consistently to stand up and stand out to challenge state power. He was considered a liberal within the church and even as a Communist by his own father (related by my GP, Dr Simon Bax in 1998), when these terms, inter alia, meant someone who opposed the government. Bax is certainly no Communist. However, even Bax's interpretation stands in need of deconstruction as he frequently appears to be defending what cannot reasonably be defended within a Christian context, a common problem among South African liberals. Written from an insider point of view, even a liberal insider perspective, his paper does not do full justice to the role of the PCSA. He is aware of the temptation to indulge in the extremes of exaltation of the role of the church, which results in 'false triumphalism' and the need to 'excoriate the role of the mainline churches' leads to slander and cynicism (Bax 1997:1).

My article does not claim to be the truth. Like Bax, I have my own limitations and prejudices in interpretation. Bax's spiritual home is a white-dominated denomination. Mine is almost totally black. That speaks to two vastly different discourses. Yet, the quest for truth must continue to challenge us. But we live in a world where the sacred and secular meet and ideology and politics affect us all. 


\section{South African liberalism}

Douglas Bax is certainly what would be described within his denomination, the Presbyterian Church in Southern Africa, as a liberal. Steven Friedman (2014:29) argues that South African liberalism presents itself as a dualism between 'the view of those who dominate socially and economically, the other points towards a freer and more equal society'. It is an ideology where:

The individual, it was thought, is free inasmuch as he is proprietor of his person and capacities. The human essence is freedom from dependence on the will of others, and freedom is a function of possession ... Society, consists of relations of exchange between proprietors. Political society becomes a calculated device for the protection of this property and for the maintenance of an orderly rate of exchange. (Macpherson 1962:3)

One can note immediately how this conflicts with the communal nature of African society. Friedman (2014:34) continues by noting that historically, 'Well before its arrival on South African shores, liberalism was ambiguous - a weapon of domination and a route to emancipation'. It also privatised and promoted cultural power in order to reduce the integrity of other cultural understandings through a 'politics of difference' in which 'the centrality of race ensured that the dividing line between liberals was primarily their response to white racial domination' in the forms of accommodation and exclusion. Both of these responses were found in the PCSA and are in need of deconstruction.

\section{Deconstruction}

There is no more amenable topic for a discussion on deconstruction in history than that of apartheid South Africa. This article will focus on one particular denominational tradition in this regard and on one particular Interpretation within that tradition. Based on Heidegger's (1962) Being and Time Holland comments that: 'Deconstruction is always a double movement of simultaneous affirmation and undoing' (Holland s.a.). The process of deconstruction involves analysing the ambiguities, which are embedded in a source in one or more of its central concepts in order to expose the contradictions, internal inconsistencies in the double movement. The process reveals the context of the creation of the source in its historical circumstances and traditions as well as in the text, revealing something of the author's life. Deconstruction is always a continuous ongoing process because meaning in language is constantly changing which indicates that no absolute meaning or interpretation of a text is possible. The sources' meaning is arbitrary because of the lack of absolute meanings and the opaque character of language, and the arbitrary and socially provided relationship between the signifying word and the concept it signifies. Language cannot generate absolute correspondences between things and their description. Later periods, even in recent history, will always see something different in a text as they deconstruct it in the context of the realities with which they live.
A recent debate to be found in history today concerns the extent to which history as a discipline can accurately recover and represent the content of the past, through the form of the narrative or literary structure of its written primary and secondary sources. Munslow (2012) argues that:

the genuine nature of history can only be understood when it is viewed not as an objectivised empiricist enterprise, but rather as a literary project which must self-reflexively take account of the imposition by historians of a particular narrative form on the past ... The fundamental function of the historian is to understand, and explain, in writing, the connections between events and occurrences in the past - working out a relationship between knowledge and explanation. (p. 1)

The task of the historian is to give evidence meaning by correlating and placing it within a particular context (Munslow 2012):

This process of contextualisation is undertaken by the historian as part of her process of interpretation by relating masses of apparently unconnected data with a consequent constitution of meaning. The evidence of the past is processed through the mechanism of inference: historians construe meaning employing categories of analysis determined by the nature of the evidence. (p. 1)

Hence, the essence of historical understanding is the ability to recognise, construct and follow a narrative story based upon the available evidence.

\section{Setting the scene}

First of all, in the unpublished abstract of Bax's paper, we note that Bax's (2013) focus is on selected areas:

- protests against the government's racial policy

- active non-violent resistance against that policy

- military service and conscientious objection. (p.1)

\section{Racism within the Presbyterian Church of Southern Africa}

In the section of his paper, 'Racism within the PCSA', Bax (2013) considers the origin of the Presbyterian Church of South Africa, formed in 1897, almost 100 years after the arrival of Presbyterians in South Africa:

Those who negotiated the formation of the PCSA in the 1890s wanted to include all Presbyterians of all races. For fear of paternalism on the part of more highly educated whites the majority of Scottish missions decided not to join it at that stage. Nevertheless, the intention was for the PCSA to be racially inclusive. (pp. 143-144)

In principle, all congregations were in principle open to all races, but separate residential areas, language and racial differences led to separate worship racially. Hence, an acknowledgment of racism was integral to any discussion of the relationship from the beginning. Bax tends to underemphasise this issue, which was a regular and critical determinant in the relationship between the two bodies of Presbyterians. 
Bax's inference is that principle and practice were two different things. There is no doubt that the Scottish missionaries of the Free Church of Scotland mission were paternalistic (e.g. James Stewart, Principal of Lovedale Missionary Institution, 1870-1905; see Stewart 1894:42-43). There was a form of perverse benevolence in paternalism and trusteeship, which was its first cousin, but the issue here was blatant racism, manifested in control and the exercise of power. From the 1820s, PCSA missions, rather than congregations, were formed among black and mixed race people and financial dependencies were formed, which remain to this day and help perpetuate inequalities. Bax continues (2013):

The different races came to have little contact except at Presbytery and General Assembly meetings and at the ordinations and inductions of ministers. White Presbyterians did not escape the racial prejudice endemic in white society. In time blacks who did visit 'white' congregations were not always made to feel welcome; some white members and indeed some congregations did not want blacks sitting with them. One Presbyterian church even roped off its back seats for 'non-Europeans'. And at one ordination or induction in a white congregation, a separate table was prepared for the preacher, a black minister, and his family! (p. 144)

While there may not have been contact within the ecclesiastical context, there certainly was in the domestic context where the relationship would be one of dominance and subservience. However, white PCSA Christians, for the most part, did not challenge racial prejudice. This was racism, not paternalism. For example:

The history of the PCSA ... has been characterised by racial segregation, racial prejudice, paternalism, and conservatism in the face of glaring injustice. (Bax 1997:19)

In the South African context, we must consider how normality was redefined in contradistinction to the apostle Paul's command in Romans 12:2: 'Do not conform to the standards of this world but let your hearts and minds be transformed ...' This demanded a repentance and reorientation of lifestyle. Then Bax states (2013):

With most of its black congregations having originated in the mission work of the Scottish Churches ... (p. 144)

This is not so; the PCSA missions, which were not full-status congregations according to racial policy (see first quotation below) like the tri-cameral parliament of the 1980s, were the result of the mission work of individual congregations, though the United Presbyterian Church of Scotland Mission and Relief Church missionaries were active in the eastern Cape (Lennox 1911:27). The problematic position was:

the PCSA for long administered them by means of its own separate 'Native Missions Committee', by 1939 renamed 'African Missions Committee'. These congregations depended on financial assistance and were regarded as continuing to need supervision by missionaries. 'Coloured' and Indian congregations fell under separate 'Extension' and 'Mission' Committees. Thus the administration of congregations was structured along racial lines, and white paternalism pervaded the system. (Bax 2013:144)
This was problematic because a racial basis was the determining factor in pursuing mission policy. Consciously, or unconsciously, the PCSA conformed to government policy prior to the institutionalisation of apartheid in 1948 and initially, at least, there was little or no resistance:

In 1962-63 that system ended. But congregations continued to be officially designated by race until 1970, ... The PCSA's General Assembly and regional courts were fully integrated, except in the Orange Free State, where separate black and white Presbyteries lasted until about 1950. (Bax 2013:144)

This is inexplicable in the light of the nature of the common business of these courts of the denomination. But racism did not only pervade the business of the courts of the church. It extended to accommodation, meeting places and appointment to responsible office, thus tacitly limiting opportunities for social interaction, just as in apartheid ideology. At General Assemblies, as with Presbyteries, commissioners were always housed with hosts of the same race until the 1980s or 1990s and after that very few whites were housed with black families. It was only in 1995 that the General Assembly of the PCSA met for the first time in a black congregation in a black township, in Atteridgeville, Pretoria:

The first black Moderator of a mixed Presbytery was George B. Molefe ... in 1953. An outstanding educationalist and community leader, he was a natural candidate to be nominated for election as Moderator of the General Assembly after this, but never was; instead white men of lesser stature were elected. The first black Moderator of a General Assembly was elected only in 1972, to serve in 1973-74. He was Dr James J.R. Jolobe, a prominent Xhosa writer and poet. His election was an act of contrition by the Church for not having elected a black person long before, as by that time he was an elderly retired minister! But it was a breakthrough: after that the PCSA elected another 6 black Moderators of Assembly before going into union with the Reformed Presbyterian Church in 1999. Of these the last was a layman, Zama Gebeda, Professor of Sociology at Fort Hare, who presided at the Assembly in 1998 and at the PCSA's closing Assembly in 1999. (Bax 2013:144-145)

This comment points to the racism inherent in the election process. Gebeda was an educationist at Fort Hare University prior to this, not a sociologist. At the time of his election he was a professor at the University of the Transkei. This statement regarding the recognition of black ministers is nothing to be proud of in a denomination that had a predominantly black membership. It was a symbol of white power, white domination and white control, even in the case of the appointments of Moderators of courts of their denomination who were actually disempowered by having the right to vote denied to them, according to the law of the church, while in office (PCSA 1960:5; 1971:60; 1990:63). However, in these early days, it was not politically correct to have black leadership so it was avoided as much as possible except when a truly outstanding candidate emerged who would not challenge the status quo and whose election would not cause offence to the white membership, as can be seen below:

The first predominantly white congregation to call a black minister was the city church in Harare, which called Herbert 
Chikomo in 1983. St Andrew's in Pretoria called Mantsi Mohapi as a black colleague minister for its inner-city ministry in 1987. In 1995, the white congregation in Adelaide called Dan Francis, an Indian. In the same year, the white congregation of St Giles in Orchards, a northern suburb of Johannesburg, called Dr Maake Masango. (Bax 2013:145; PCSA Proceedings 1985:221, 232)

None of these were regarded as a threat to the status quo. It is perhaps of note that Chikomo was elected in a postcolonial Zimbabwean context. Mohapi was severely criticised by his black colleagues for accepting this appointment. Masango had studied in America for more than 10 years and had only recently returned to South Africa:

In 1985, the Assembly agreed that a subcommittee be appointed to investigate racial issues such as the separate training of students for the ministry (which largely continued despite being no longer enforced by the law) and congregations' failure to call ministers across the racial divide. (Bax 2013:145; PCSA Proceedings 1985:221, 232)

Bax is silent on the outcome of the work of this committee. This was not something to be admired but lamented as it was a clear indication of an awareness that something was far wrong. It was also a common Presbyterian strategy (as in other organisations) to appoint a committee when the expected desired result was inaction. But what is clear is that nothing changed. Black candidates for the ministry were trained at the Federal Theological Seminary of Southern Africa from its establishment in 1963 while white candidates were trained at Rhodes University from 1947, an arrangement made with the university and the Methodist Church of South Africa a year before the institution of legalised apartheid.

Racism was built on the principle of différence, and economics was one of its referents:

Economically the PCSA remained a Church with severe racial disparity. The Assembly set minimum stipends, but each congregation paid its own minister. ... As a result black ministers' stipends were generally much lower, because most black congregations, though much larger than most white congregations, were still much poorer. Indeed for a long time the minimum stipends for whites and for blacks were set at different levels. Stipends that fell under the minimum were subsidised from central funds. However, most black ministers were on the minimum or close to it and struggled financially, while no white ministers were on it. (PCSA Papers 1975:32f.)

Tucker (2012:2) simply referred to the perception of black ministers regarding this state of affairs as 'unjust' but, further it was a blatant denial of the gospel because many black ministers in terms of workload had outstations to cope with in addition to their centralised main station, and often far greater numbers of members to minister to. Living far from urban centres, their living expenses (e.g. shopping) were higher than in their colleagues' parishes:

Only in 1981 did the General Assembly charge three committees to investigate together whether all ministers could be paid from a central fund 'in order to establish non-discriminatory stipends'. But the next year the Assembly dropped the investigation. A critical factor was that no black commissioner stood up to speak in support of the proposal at either Assembly. (Bax 2013:145; PCSA Proceedings 1981:182, 201; 1982:243)

To attribute a General Assembly decision to the absence of comments from black speakers is problematic. Black commissioners hardly ever addressed the Assembly on any topic. The RPCSA had a system of centralised stipends, which worked well for them. The fear of white PCSA ministers was that the centralisation of stipends would lead to the equalisation of stipends and, consequently, a lowering of their income. The role of black commissioners is largely irrelevant. To suggest that their views actually counted for anything was never a matter of concern. This also raises the question why white commissioners were not concerned about the low level of their black colleagues' stipends and why they constantly voted to maintain substantial differentials each time a minister's stipend came up for review? The mention of the sister church of the RPCSA is relevant because:

It should also be noted that from 1937 onwards several attempts were made to unite the PCSA and the BPC (later the RPC). Until the 1990s all these failed because BPC leaders feared that they and their congregations would not enjoy equal status and dignity in a united Church. (Bax 2013:145)

But here Bax only tells part of the truth. The PCSA itself had serious concerns regarding being swamped by a black majority as well as significant antipathy to sharing in one denomination. Indeed, in the early 20th century, the General Assembly focused on temperance, gambling, chastity and sabbath-keeping more than on racial and political justice (PCSA 1898:68f.; 1900:175f.). These issues had been particular foci of the South African Native Affairs Commission (Lagden Commission 1903-1905; cf. Bax 2013:146; PCSA 1898:68f.; cf. Bax 2013:2). But what about white members? Did they not also suffer from such problems?

Bax then proceeds to discuss 'Racism in Society and its background prior to 1960':

With a majority of white members in a segregated society, its natural tendency was to be politically conservative and wary of radical political protest despite the grave injustices in society. Indeed, the dominant theology among English-speaking whites in South Africa tended to separate religion and politics.... But like the other Churches it for long failed to confront racism in a radical or effective way. (Cochrane 1987:65)

This 'natural tendency' was normative; yet it was contrary to Christian values. Then Bax turns his attention to: 'Protests against Government Policy' from 1960 onwards and focuses on the 1960 World Council of Churches' Cottesloe Consultation on apartheid called to meet 'in the wake of international reaction to the Sharpeville Massacre on 21 March 1960' (Bax 2013:3). The PCSA participated as one of the member churches of the South African Council of Churches. The Consultation produced a Statement, which the PCSA General Assembly approved and encouraged congregations to study the Consultation's reports. It is doubtful if the Statement was ever studied or 
any further action was taken, if the document was studied in the first place.

Various PCSA Assemblies also protested against:

- the infamous 'church clause' in Dr Verwoerd's Native Laws Amendment Bill, which sought to prevent blacks or predominantly black congregations from meeting in 'white' urban areas (the 1957 and 1962 General Assemblies)

- the General Laws Amendment Act, which gave the police the right to detain blacks without charging them and to control their movements (1962 and 1963 General Assemblies)

- the 90-day detention clause and detention without trial (1964 General Assembly)

- the requirement of permits for mixed audiences and aspects of the Suppression of Communism Act and the amended Criminal Procedures Act (1965). (PCSA Proceedings 1957:104, 107; 1962:45-48, 107; 1963:38; 1964:23f., 119; 1965:26, 113)

On the other hand, these protests showed little outrage. Indeed from 1964 to 1966 the Assembly's criticisms of the Government were compromised. For these 3 years Dr R.H.W. Shepherd was the Assembly's appointed convener of its Church and Nation Committee. Shepherd had been a prominent Scottish missionary, Principal at Lovedale for many years and Moderator of the Church of Scotland for one. After retiring he joined the PCSA. (Bax 2013:147; Oosthuizen 1970:119-120).

At least the General Assembly was made aware of the political events that were becoming normative in society and had an opportunity to respond. However, as Bax states elsewhere, whether this information was disseminated to congregations is far from clear. But what is significant here is Shepherd's sudden rise to power over an important General Assembly committee. He was past retirement age, a wellknown conservative and still a minister of the Church of Scotland. He was certainly one who would promote the political status quo despite his many years of service of a black church since 1920. His prestige in the South African mission church scene gave him a status that was very welcome in the PCSA. Shepherd clearly sought to soften any criticism of the government:

In 1966 the Assembly likewise qualified a statement against severe Government restrictions on the freedom of speech by supporting the Government's attempt 'to prevent unlawful subversion'. (Bax 2013:147; PCSA Proceedings 1966:21, 108)

The fact that the General Assembly turned to Shepherd and responded as it did to Shepherd's committee's guidance could be interpreted that this was a more accurate reflection of the PCSA's actual views. Bax refers to the naivety of the General Assembly and its committees on various occasions but this assumption has never been interrogated. This naivety was still being expressed and justified almost 20 years after the introduction of legalised apartheid:
The irony is that Shepherd, the convener of the committee that sponsored these decisions, was an ex-missionary from the Bantu Presbyterian Church, which had broken off talks about union with the PCSA for fear of the PCSA's racial conservatism.

From 1968 and especially 1979 onward the Assembly's Church and Nation Committee brought increasingly radical proposals to it that provoked heated debates. Because the majority in Assembly was always white and for a time most black commissioners hung back from debate on political issues, those who led the fight for a more radical stand faced strong opposition and met some setbacks. Moreover, as in other Churches, at grassroots level many white members dissented from the positions that the Assembly began to take. (Bax 2013:148)

In 1969 Harold Munro persuaded the Assembly to turn down a proposal to endorse the [South African Council of Churches'] Message to the People of South Africa (1968). The following year, however, when a summary of the Message was presented to it, the Assembly reversed this decision by endorsing the Message's critique and sent the summary to all Sessions to study. (PCSA Proceedings 1969:57, 130f., 1970:49, 149. On the Message see Bax 2013:150-151; De Gruchy 1979:115-123; De Gruchy \& De Gruchy 2005:112-120)

This testifies to 'The power of one' in the PCSA and might be interpreted variously. Firstly, the General Assembly was a fickle church court whose membership changed annually; secondly, one powerful speaker could sway the moral courage of a General Assembly; thirdly, the Assembly commissioners may not have been aware of the actual contents of what they were voting for because commissioners were notorious for not reading Assembly papers prior to the meetings. In addition, many may not have been competent in English:

In 1971 the Assembly commended to ministers, Sessions and members for study all the publications of the 'Study Project on Christianity in Apartheid Society' (SPRO-CAS) produced in the wake of the Message. (Bax 2013:151)

Commendations to study documents were just that. Bax refers to the conservatism of ministers who would not refer such issues to congregational scrutiny for fear of being seen as part of the radical wing of the church. They might also fear that their congregational support, financial and otherwise, might disappear making their tenure uncomfortable, if not impossible.

As the struggle against apartheid accelerated, international institutions became involved, including church bodies. In 1970 the World Council of Churches (WCC's) Programme to Combat Racism made grants of $\$ 20000$ to 19 organisations, including SWAPO, the ANC and the PAC for the purpose of promoting peaceful change. Bax (2013) commented:

This incensed the Government and the media and caused a general outcry among whites in South Africa. Prime Minister B.J. Vorster put heavy pressure on the South African member Churches of the WCC to resign from the WCC. He threatened action if they did not at least dissociate themselves from the WCC or tried to transmit money to it or to send representatives to any of its conferences. The General Assembly of the PCSA, meeting in Cape Town, was the first national synod of these 
Churches to meet. It thus felt the main brunt of this pressure, and its response was likely to influence the other member Churches. As a result, 'all eyes were on the General Assembly of the Presbyterian Church of Southern Africa' (De Gruchy 1979:132; De Gruchy \& De Gruchy 2005:123-124). The day before the issue was debated four of PCSA leaders agreed to accept an invitation to lunch with Vorster at his Groote Schuur residence. This added to the drama. One was Harold Munro. The first to address the Assembly on the issue the next day, he made a forceful speech to persuade it to take the PCSA out of the WCC. After an emotional debate the Assembly refused. It did dissent from the WCC decision and from guerrilla violence, and in protest also suspended its membership fees. (p. 151)

Yet, the PCSA General Assembly did express dissent:

\begin{abstract}
'at least as much from the violence inherent in the policies of the Government' and, in an attempt to let the case for the other side be heard, urged the SACC to invite the WCC leaders to South Africa to discuss their point of view with Church leaders. It also hit out against all Vorster's threats and against his blatant public misrepresentation of the views that Beyers Naudé and an Anglican priest, Robert Mercer, had expressed on violence in South Africa. It boldly reminded Vorster that its only Lord and Master is Jesus Christ, that it may not serve other masters, and that its task is not necessarily to support the politics of the Government in power but to be faithful to the Gospel of its Lord and to seek justice for the afflicted and liberty for those who are oppressed. (Bax 2013:151-152; PCSA Proceedings 1970:16, 18, 60$63,77,178 f$.)
\end{abstract}

Bax's contradictory account of this rather unfortunate affair leaves a number of questions unanswered. Why would Vorster invite PCSA ministers to lunch the day before an important debate that centred on the relationship between church and state as well as an international ecclesiastical matter when he had clearly declared his views which were not on the table for debate? Why did the ministers accept the invitation when they were predominantly against the involvement of the church in political affairs? It is inconceivable that the matter of the WCC was not discussed in depth. And by what authority could Vorster seek to influence church decisions when he himself told church ministers to keep to their religious calling and not interfere in politics? Is it in the nature of and in the best interests of the church and its faith to be colluding with power? In the nature of things, ministers who were opposed to Vorster's views would never have accepted an invitation to lunch with him. Were they so deluded in thinking that they could change his mind? None of these questions have ever been satisfactorily investigated or answered in a manner that made clear the position of the membership of the denomination.

As was often the case with the PCSA, compromises were reached simply as the result of the superior knowledge on the part of whites of the rules of debate and law, practise and procedure. This was based on expediency rather than on the rights or wrongs of the matter under consideration. According to Bax (2012:151 n.42), the effect of the final outcome of the debate 'was to whittle away some of its more radical details' as the result of the proposals having been debated clause by clause. Then he goes on to claim: It seems problematic to describe this as the PCSA seeking 'to project a stance of neutrality and balance' when this is exactly what it was intended to achieve. Clearly in voting, commissioners were not in total solidarity with either view because procedural manoeuvres had to be employed.

One of the recurring problems with decisions taken by PCSA General Assemblies is that there was no way to enforce them. For example, we do not know the extent to which its liturgical Declaration of Faith, or other anti-apartheid resource, was used despite its status. The author himself has never heard the creed used in a PCSA congregation. Also, at issue here is the lack of vernacular translations of such documents, without which it was impossible for the majority of church members to reflect on their contents and participate in debates:

Afrikaans Reformed churchmen had repeatedly accused the English-speaking Churches' opposition to apartheid of being motivated by a naive 'liberal' political philosophy derived from the Enlightenment. The Declaration made clear what really motivated it: that Christ is Lord over the whole of life, public as well as private (which Calvin had taught in the 16th century and Karl Barth re-emphasized in the 20th). This opposed the 'two spheres theology' of the NGK, which attributed ethical authority in the public area to what it perceived as the orders of creation and culture instead of the gospel. (Bax 2013:152; PCSA Proceedings 1971:36, 124 no. 20)

While this is true theologically, the Afrikaans Reformed churchmen touched on the truth in a practical sense. Liberal political views often made for difficult partners with Reformed theological declarations, especially when liberalism in South Africa suffered from a variety of expressions often ranging from communism to conservatism depending on who was defining, defending and promoting it.

Political affairs were advancing apace as were the General Assembly's responses:

In 1979 the PCSA Assembly inter alia sharply denounced 'the public immorality in high office revealed in the whole Information Department scandal' and 'the fundamental political immorality' of Prime Minister B.J. Vorster in calling a general election in 1977 without revealing that the Government had secretly funded The Citizen, a National Party newspaper. In compiling the Assembly Papers the Business Committee and the Clerk of Assembly declined to print three proposals of the Church and Nation Committee that sharply attacked the Information Department for fear that their wording would provoke the Government to ban the Papers. The Clerk requested the convener of the Committee to revise them. He (the convener) refused, and the. (PCSA Papers 1979:36; PCSA Proceedings 1979:45f.)

Again, we note the minority view expressed by Bax being subverted by 'senior' ministers of the PCSA which represented all presbyteries throughout southern Africa. The 'fear' referred to was based in a racially bound defective theology, which contradicted the theology of the documents accepted, at least in principle by the General Assembly. There 
was no theology of hope here; just a theology of fear, control and subversion (Bax 2013:155).

Bax (2013) is clear about the failure of the PCSA to declare itself unequivocally:

In fact for all the sharp opposition to the Government and apartheid that the PCSA expressed at times, like the other Churches it never went so far as actually to declare the liberation struggle a just revolutionary struggle, though a 1985 statement came close to this. (p. 156)

At this time, a new force was mobilised which would cause ripples throughout the PCSA through conscientisation, but was not sufficient to effect any substantial change:

In 1985 the black ministers of the PCSA constituted the Black Ministers' Consultation, in order to work for black solidarity and empower black leadership in the Church. ... In 1987 it was renamed the Presbyterian Black Leaders' Consultation (PBLC). ... This was an important step in a white-dominated Church. Prior to this those who had wanted the PCSA to take a more radical stand against apartheid had often been frustrated by the fact that blacks abstained from joining in the debate or even supporting them with a solid block of votes at Assembly. At last black commissioners at Assemblies and in some Presbyteries now began to be much more outspoken in debates on political issues and to vote with much more solidarity. This in turn forced the more conservative white commissioners to see that their positions were biased and racist. As a result the PCSA's stand against apartheid now began to be more emphatic and consistent. (Bax 2013:156-157)

Rev Professors Jerry Pillay and Maake Masango (sometime members of the PBLC, in a discussion at Pretoria on 05 April 2017) affirmed the value of the contribution of the PBLC. Yet, this raises a serious issue regarding the commitment of black ministers. It is necessary to question the reason for the reticence of black ministers. Prior to 1985, they had still been present at General Assemblies and could have caucused (consulted) among themselves to challenge racism within the church. According to Bax's inference, there was no real reason for their compliance and silence. So we need to penetrate behind the scenes to another issue which was controversial and most certainly racially defined. This was the matter of stipend differentials. Even after the declaration of a minimum stipend, black ministers were paid far less than their white colleagues and many of their congregations could ill-afford to pay them even the minimum. This had led to the introduction of the ultimate instrument of control in the form of stipend supplements (mentioned above) which often to this day prevents ministers from acting according to their consciences in many matters. Others have been co-opted with various inducements, promises of high office and gifts. The constant fear of black ministers, therefore, was intimidation and even persecution.

Then in 1985, one of the most significant and controversial ecumenical documents ever published in South Africa was released, The Kairos Document. It was not ecumenical in the sense that it was published by churches but by concerned ministers and laypersons regardless of denominational affiliation. It challenged forms of theology, which were inconsistent with the gospel, State Theology and Church Theology, and promoted a Prophetic Theology. The PCSA was steeped in a combination of church and state theology. Yet:

In 1986 the Assembly welcomed the publication of the Kairos Document and endorsed aspects of it. ... The qualification in the endorsement resulted from hesitation about the way in which the document demonised the rulers as well as apartheid itself. (Bax 2013:158)

It is not clear what the actual hesitation was. Bax's explanation for hesitation regarding the demonisation of rulers was explained in his section on 'Active non-violent resistance against apartheid':

Mere protest in a society like South Africa's was of little use if people were not prepared to back this up with active resistance. Whatever protests they did make, the Christian Churches, including the PCSA, for long never thought of moving from the comfort zone of statements of protest to the more costly path of action. All the white-dominated Churches in southern Africa were out of touch with anti-apartheid movements. For instance, no Church, not even the Christian Council, considered joining any of the early demonstrations against apartheid like the Defiance Campaign in 1952. Church leaders were conspicuously absent from the Campaign, even though it opened with days of prayer and was accompanied with nightly church services among blacks. The white leaders of the Churches were generally conservative and would have seen such support for the Campaign as engaging the Church too directly in politics. Thus the Church's opposition to apartheid was for long limited to mere words - some sharp, some far too mild - without any action. (Bax 2013:157; cf. Bax 1997:22)

The concern here was the manner in which ministers who had been theologically trained still believed in the separation of religion and politics and accepted apartheid as a 'normal' state of affairs.

But to return to the topic of demonisation, the PCSA itself became used to demonising its own. I only need to mention the name of Rev. Dr Mamabolo Raphesu, to bring some ministers near to a state of apoplexy. There was never so courageous a minister as Raphesu who suffered for his faith and worked it out in the context of black poverty and deprivation and detention without trial. When I first met him, he was a student at Fedsem, who had spent time in detention, and was revered by both black students and ministers and was detested by white ministers for his antiapartheid activities which, were far in advance of his denomination. Soon afterwards I was introduced to a senior PCSA minister as a tutor at Fedsem and was challenged to justify our training of radical ministers. Without being given an opportunity to respond, I wondered how and why, if this was the case, Raphesu had ever been promoted as a candidate for the ministry in the first place?

At grassroots congregational level, little was changing but where change was taking place it was significant though not enduring: 
The social colour bar that finally culminated in apartheid in the 20th century left very few integrated congregations in South Africa. After Sharpeville Brian Stumbles, the Presbyterian minister at Vereeniging, began occasional multi-racial services in his church. In the wake of this bullets were fired through its windows (Robertson 1997:10). But it was Rob Robertson, then a minister in East London, who really faced up to the need for the Church to do something to oppose segregation. Already before Sharpeville he had determined to start a congregation that would bring white and black, rich and poor, together across the racial and social divide ... The North End congregation continued until the end of 1970. (Bax 2013:157-158)

Sadly, there was to be only one more experiment of its kind in Johannesburg, also promoted by Robertson. It lasted from 1975 to 1990 (Robertson 1999), but the concept and reality of the integrated congregation just did not appeal sufficiently without a charismatic leader like Robertson to promote it.

\section{Active non-violent resistance against racial policy}

However, Rob Robertson was kept busy promoting an innovative non-violent methodology as an alternative challenge to apartheid. In 1970, he persuaded the Assembly to instruct the Church and Nation Committee 'to take up the study of non-violent means of defence and social change' (PCSA Proceedings 1970:35, 51, 150). At first little happened. But it was Robertson himself who was in the vanguard of non-violent resistance to apartheid:

In 1980-81 the convener of the Church and Nation Committee asked him to draft material and proposals that would move the PCSA toward actual non-violent resistance against the policies of the Government. In 1981 the Committee presented these to the Assembly. After a tense and emotional debate the Assembly, in the end, voted to defy the Government on three issues:

- the Group Areas and Urban Areas Acts - by supporting any ministers who defied these Acts by living in areas prohibited to their races, in order to live near their congregations

- the banning, for political reasons, of people [like Beyers Naudé] and literature - by urging ministers to disregard the restrictions against quoting them when preaching

- the Prohibition of Mixed Marriages Act - by calling on ministers to marry couples across the racial line. (Bax 2013:159; PCSA Proceedings 1981:182f., 186, 202)

Was this change of mind the result of a realisation that increasing violence was not in the best interests of white members of the denomination or was it simply viewed as a less costly form of discipleship? It would be interesting to know the extent to which these decisions were implemented. The refusal to implement non-violent action was perhaps still considered to be too strong a response for members who supported the status quo. Bax (2013) offers an example:
These decisions were costly, however: partly because of them several congregations, including at least one large and wealthy one, left the PCSA. (p. 160)

Here, Bax links sacrifice to the economic loss incurred. Challenging apartheid was seen by some on the church to be too great a sacrifice to make as it could affect the financial sustainability of congregations, especially wealthy ones. Threats like this have been used frequently to determine or limit policy decisions:

Already by April 1982, however, the debate that this helped to stir up pushed the Prime Minister, Mr P.W. Botha, to the point of declaring his willingness to review both the Mixed Marriages Act and Section 16 of the Immorality Act, if the Churches could agree (which meant if the Afrikaans Reformed Churches would accept a change in these laws). Three years later, in 1985, these Acts, which together were the most ideological in the edifice of apartheid and basic to it, were in fact repealed. This was the first real critical step in dismantling the whole apartheid system. (Bax 2013:160; PCSA Papers 1982:31)

This was a positive achievement directly linked to a PCSA initiative. But it was less costly in the eyes of members than support for the armed struggle.

Meanwhile in 1981 the Assembly:
... resolved that in future no applications for permits in terms of the Urban Areas Act would be made for any of its commissioners to attend any of its meetings - and encouraged Presbyteries to make the same decision for their meetings. (Bax 2013:160; PCSA Proceedings 1984:310, 341)
In 1988 Robertson, after notifying the Department of Home Affairs of what he intended to do, drove Walter Wink, author of Jesus' Third Way advocating non-violent civil disobedience in South Africa, from Lesotho to South Africa across an unpoliced border. Wink preached at St Antony's and addressed the Convocation of Churches in Johannesburg that launched the 'Standing for the Truth' non-violent resistance campaign against apartheid. (Robertson 1999:164)

One of the most critical issues which challenged churches during the 1980s related to the campaign in favour of disinvestment and sanctions. In 1985 the SACC gave its support to disinvestment and boycotts as a non-violent means to press for fundamental change. The issue came to the PCSA Assembly in 1986 and 1988, and as with all the other 'English-speaking' churches except the UCCSA, failed to give this clear support or propose any effective alternative:

This was a critical failure of judgement, as the campaign against investment and particularly against foreign loans, was a decisive factor in the struggle against apartheid, combined with the rising tide of internal resistance and unrest. However, the PCSA's hesitation was largely motivated by concern about how much it would worsen the suffering of the poor (as later research showed that it did), when it seemed that the struggle to bring down the Government would still take a long time. (Bax 2013:161)

This was a typical controverted reason. Did anyone ask the poor what they thought and were prepared to bear for the sake of their human rights and human dignity? There is no 
evidence extant that the PCSA did. Here we note a reversion to paternalism where one group of people decides what is in their best interests without consulting them. The truth lies nearer the other extreme of how much it would harm the wealthy who had the bulk of the nation's assets and resources at their disposal and in their control. The poor were hardly at the centre of concern in the white congregations of the PCSA:

Individual Presbyterian ministers and members took an active stand against apartheid, and some ran into trouble as a result. ... Some ministers and members took part in the protest marches that characterized the last period of Nationalist government, despite some marches being banned. ... A few Presbyterian ministers and members were arrested and detained during other marches, though only briefly. (Bax 2013:161)

'A few', 'some', 'individual ministers': these were the exception rather than the rule acting on their personal initiative and taking substantial risks. Such as these were to be found in all mainline denominations (see Bax and conscientious objection below).

\section{Military service and conscientious objection}

I quote at length here because this was Bax's cause celèbre. Military service and conscientious objection was a most emotive and contentious issue because of the involvement of young white men inter alia from within the PCSA and beyond; but this was one of the main results of apartheid which implied costly sacrifice from the children of its supporters:

Although not seen as such by many, the most critical moral issue that whites who opposed the Government faced was that of military service and conscientious objection. The military call-up of young white men had been compulsory since 1967, and the Government had gradually increased the period of national service and subsequent annual camps. The Defence Force maintained the political status quo against any attack from outside and was there to back up the police against any attack or agitation from inside its borders. Along with the police it therefore served to defend and enforce the whole apartheid system. ... In 1971 and repeatedly thereafter the PCSA Assembly supported the right of conscientious objectors to object to military service on what the State called 'political' (Just war theory) grounds as well as pacifist grounds and paid tribute to those who did object. In 1973 it called on congregations to pray not only for servicemen but also for the men in 'organisations seeking to change Southern Africa by violence'. (Bax 2013:162; PCSA Proceedings 1973:111, 138)

Again, the level of response is unclear:

Then in 1974 the annual three-day National Congress of the South African Council of Churches met at Hammanskraal. On the first day of the SACC Congress several black delegates sharply criticized the stand of the Churches on the growing strife in South Africa. The author [Bax], as one of the PCSA delegates, had long been concerned about the Churches' failure to apply the criteria of the 'just war' to the South African situation. He posed the question whether it was not time to challenge young white men to consider conscientious objection. ... It deplored all violence as a way of solving problems but specifically declared that the SA Defence Force was being used to uphold an unjust and discriminatory political system. It therefore posed the question 'whether Christ's call to take up the Cross and follow Him in identifying with the oppressed does not, in our situation, involve becoming conscientious objectors' and proposed that the SACC challenge its member Churches to call on their individual members to consider refusing military service. It also questioned the role of military chaplains in supporting the morale of the Defence Force and raised the issue of ministering to the other side. ... when the proposal was put to a final vote again, as a complete statement, it strangely enough received 48 votes in favour to 0 against. It became known as the Hammanskraal Resolution. (Bax 2013:162-163)

\section{Prime Minister B.J. Vorster stated:}

I want seriously to warn those who are playing with fire in this way to rethink before they burn their fingers irrevocably. (Die Burger 3.9.74, in Balia 1989:58)

Here the true Vorster emerges. He would brook no religious involvement in matters secular (read political) as if they were separate entities in the one world created by God where everything he had created was under his dominion. But the poor response to the church's call is yet another demonstration of the white population's support for apartheid, or its anxiety not to challenge it:

Harold Munro as the 'Junior Clerk' of the PCSA now pressured the Moderator, James Jolobe, and the General Secretary, Edwin Pons (who at Hammanskraal had at the end of the debate finally voted in favour of the whole resolution!) into supporting a hasty public statement to dissociate the PCSA from the resolution. According to the Church's own laid-down rules, however, this statement was blatantly ultra vires. (In a footnote Bax commented: 'The Assembly had laid down that such public pronouncements on behalf of the PCSA could be issued only if drafted in consultation between the Moderator, the General Secretary and the convener of the Church and Nation Committee. This rule had always been strictly observed, but on this occasion the convener of the Church and Nation Committee, Luther Mateza, was not even consulted. The statement was thus blatantly out of order'). (Bax 2013:164)

Moreover, the Executive Commission that met in place of the General Assembly that year rejected an overture from the Bryanston United Church to endorse this public statement against the Hammanskraal resolution. But the damage had been done. (Bax 2013:164)

Here again, we note the preponderance of conservative PCSA leaders' and their duplicity in manipulating church law in their own favour to support a pro-apartheid stance:

Because a public call to object to military service was something new at the time and few people had given much thought to the issue, the proposers of the resolution at Hammanskraal thought it politic to 'challenge' the Churches to call on their members to 'consider' conscientious objection. But now that the public debate had been opened, the proposer prepared a more categorical call for conscientious objection for the SACC National Congress the following year. Beyers Naudé again agreed to second the motion. John Rees [Methodist and SACC General Secretary], however, had had enough. Fearful of the consequences that a blatant flouting of the new law might mean for the SACC, and perhaps its staff, he secretly organized them to filibuster, so 
that the proposal was moved further and further down the agenda. When the proposers protested, he smoothly assured them that it would still be dealt with. But in the end no time was left before the Congress ended. Afterwards Rees went to confer with Harold Munro, and in 1976 Munro saw to it behind the scenes that different delegates were nominated to attend the SACC National Congress (PCSA Papers 1975:20). The SACC never publicly discussed the issue again, until in May 1979 Rob Robertson re-introduced it in his SACC-sponsored leaflet NonViolent News. (Bax 2013:165)

This was typical of the inter-church and ecumenical collusion which took place to subvert discussion of critical issues by removing the 'obstacles' to the maintenance of the status quo:

A few members of the PCSA, however, saw to it that the issue of conscientious objection remained on the agendas of its Assemblies. From 1979 onwards the Assembly regularly paid special tribute to Peter Moll, Richard Steele, Charles Yeats and other conscientious objectors as 'courageous confessors of the faith'. In 1981 it recognized the bona fides of Christians who in good conscience took up arms to fight for 'liberation' as well as those on the other side. It also agreed to send study material on 'war, revolution and military service' to congregations and called on ministers to include instruction on this issue in their confirmation courses. (Bax 2013:166; PCSA Proceedings 1981:186, 202)

At least, in this case, some responses were received (PCSA Proceedings 1983:27, 38f.):

In 1982 the Assembly agreed to set up a special committee (later renamed the 'Committee on the Bellum Justum') to study the issue of military service and conscientious objection (PCSA Proceedings 1982:251, 257f). At first the attempt to smooth the way for this committee by having non-controversial conveners nominated and appointed for this committee delayed its effectiveness. But in 1985 the committee persuaded the Assembly to send a statement to the Ministers of Law and Order and of Defence that it viewed the violent upheavals in the country as expressing the 'legitimate' and 'unspeakable ... anger and frustration of an oppressed people', that the police and the army in the townships 'must be seen as the instruments of an oppressive and unjust regime', and that the use of white conscripts in this way was wrong. It further supported conscripts' right to refuse such duties and extended 'pastoral support' to any who did object. (Bax 2013:166; PCSA Proceedings 1985:202, 230f.)

Until 1988 the Assembly had not come out in explicit support of the End Conscription Campaign (ECC), but it now 'utterly' deplored the Government's restrictions on the ECC and its 'undercover campaign to smear and harass' it, as violating the rule of law and the right to freedom of speech. It called on the Government to unban the ECC immediately and offered to support Presbyterians in the ECC who resolved to disregard the restrictions and continue its work. It called for alternative national service to replace imprisonment for all bona fide conscientious objectors. (PCSA Proceedings 1988:180; cf. Bax 2013:166-167)

'Non-controversial' meant compliant so that whites were not upset or estranged from the church. It was only after successive states of emergency that the PCSA took a firm stand against conscription. Significantly, this was the time when the number of deaths among conscripts was increasing both within and beyond South Africa:

In response to a motion from the floor by a young minister, Rod Adamson, the same Assembly declared 'the actions of all the parties to the South African civil war currently being waged, both beyond its borders and within its borders to be unjust and wrong'. It called on all Presbyterians 'as a matter of urgent Christian witness' therefore to withdraw from, or refuse to participate in, the conflict or else 'to exercise non-violent alternatives'. (PCSA Proceedings 1988:180f., 193, 196)

This motion offered a good example of the 'church theology' that the Kairos Document had criticised in 1985-86 as an equal condemnation of all violence instead of differentiating between the violence of the oppressive perpetrators of apartheid and the responsive violence of its victims (PCSA Proceedings 1988:180f., 193, 196).

In 1990 the Assembly finally endorsed a full report on 'The Different Approaches to the Ethics of War and Conscientious Objection' from the Bellum Justum Committee (PCSA Papers 1990:44-57, PCSA Proceedings 1990:166, 188). This challenged the principle of service in the SADF and dealt with the issue of a just revolution. By this time, however, the political situation was changing rapidly, and the issue of military service was becoming much less critical. The same Assembly adopted the following statement that frankly recognised how critical the issue had been and the Church's failure in its response to it:

The Assembly expresses repentance that our Church failed to take a clear, strong stand long ago in favour of conscientious objection to serving in an army that was used to defend the apartheid system by military threat and action. (Bax 2013:167; PCSA Papers 1990:44-57; Proceedings 1990:166, 188)

\section{Too little, too late?}

At the Rustenburg Conference of Churches in 1990 a Presbyterian delegate tried hard to get the Conference to include in its Resolution a statement of repentance for the failure of most Churches to support conscientious objection to military service. Nico Smit of the NGKA was the only delegate who spoke in his support; the other delegates refused to include any mention of the issue of military service.

The issue of military chaplains was also controversial. In 1985 Rob Robertson persuaded the General Assembly to adopt a proposal to send chaplains to serve Umkhonto we Sizwe and Apla, if these would accept them. In 1988 a meeting was held with ANC and PAC leaders in Harare to discuss this. Even though nothing came of it in the end, the PCSA was apparently the only Church to moot something like this. (Bax 2013:168)

This was a commendable step - to offer pastoral support to both sides in the conflict:

The same Assembly protested against the prohibition and punishment of conscientious objection on 'political' grounds by ruling that no Presbyterian chaplain might serve as an adviser on the Board for Religious Objection [the Board was appointed to decide whether applicants were genuine pacifist objectors or not]. The PCSA was the only Church to take this stand. (Bax 2013:168) 
Again, this was a commendable step:

The long struggle to get the PCSA Assembly to move towards a radical public stance on the issue of military service was thus at last succeeding. The problem had not only been that white members of the PCSA, like those of other Churches, were brainwashed by the Government's propaganda that the liberation movements were dangerous, Communist-controlled organizations; black commissioners to Assembly had also failed to give the issue any outspoken support. Instead they stood aloof from what they blindly called a 'white issue', because their sons were not being called up. It was, of course, also more dangerous for blacks than for whites to make a public stand on the issue. Government spies were known to attend church gatherings. (Bax 2017:167)

This was a natural response from blacks who has historically been denied permission to bear arms in periods of conflict, but were deployed in a non-combatant capacity (Roux 1948:311-325).

\section{Conclusion}

Bax's conclusion summarises his dominant discourse:

The PCSA, then, has much failure in its witness to repent of, but, by the grace of God, also much to be grateful for - much more to be grateful for, certainly, than a few critics ... have suggested. In some ways indeed it was ahead of the other Churches. On the other hand it must be conceded that the relevant Assembly resolutions had a limited impact at the level of local congregations. Many ministers failed to convey to their congregations what the Assembly had resolved on controversial issues or to take as stand on them. Some lacked enough concern to do so; some feared to alienate their members. Such failure at grass roots level happened in all the Churches that opposed apartheid.

The PCSA seems to have been the first Church to issue a statement of serious repentance for its own failure and the failure of its members to oppose apartheid more resolutely. In 1990 its Assembly hailed the promise of a new, democratic and just Constitution for South Africa and on behalf of the PCSA expressed repentance for all the many ways in which we, as Presbyterians, have collaborated or compromised with the apartheid system and failed to stand against it with enough prayer, courage, determination and self-sacrifice. (Bax 2013:168; PCSA Proceedings 1990:175, 190)

It instructed that a short liturgy of confession along these lines be distributed to all congregations in South Africa for use at special services of repentance on Sunday 16 June 1991 (Soweto Day). How many of its ministers and congregations actually held such services or used the confession of sin on that day, however, is unknown. (Bax 2013:169)

In his comments regarding a 'few critics', Bax (1997:6; 2013:146, 148, 151) is referring primarily to academics Charles Villa-Vicencio, Barney Pityana, John de Gruchy, J.C. Adonis, Hoffie Hofmeyr and Gerald Pillay on matters of both detail and interpretation.

Bax's explanations consistently present an apologia for the actions of the PCSA even when he is deeply opposed to its decisions and lack of action. Consequently, he often appears to be defending the indefensible, a common problem among
South African liberals. Written from an insider point of view, even a liberal insider perspective, his paper does not do full justice to the role of the PCSA. If the attitude of the PCSA was as Bax describes it, then it was guilty of a lack of moral conviction and moral cowardice when it came to enacting its decisions.

In preparing the PCSA's submission to the Truth and Reconciliation, Bax (1997:10) laments the failure of ecumenical attempts at organic union (to which he is firmly committed personally). He continued: 'Nevertheless a serious question mark does hang over the commitment of the PCSA to nonracialism.' He described the report of a Moderator of General Assembly who had undertaken to visit presbyteries. Bax (1997) reported that:

He had sensed that behind the rationalizations of many who opposed union was the fear of a black majority, or, to put it the other way round, the desire to remain a white majority church. (p. 10)

It has to be said that Bax is a person of considerable integrity who demonstrates considerable and consistent frustration in dealing with his own denomination's history of apartheid. Deconstructing his work is a matter of reading into and interrogating what he has written. If the writer identifies himself or herself and his stances on matters religious and political, his presuppositions and prejudices (assuming she or he is aware of them), it becomes easier for the reader to interpret what is presented. For instance, with regard to the relationship between politics and religion, it is clear that to claim to be apolitical is actually to have adopted a political position. But the same might be concluded that to be political might also indicate a distancing from politics to avoid too deep an engagement or investigation of the finer points of interpretation involved.

In the end, deconstruction is a matter of perspective and intent and this involves the question of truth - what truth and whose truth? It is a matter of integrity leading people to conclude whether or not we may be entrusted with the truth of the past and, more importantly, the future of the truth.

\section{Acknowledgements Competing interests}

The author declares that he has no financial or personal relationships which may have inappropriately influenced him in writing this article.

\section{References}

Balia, D.M., 1989, Christian resistance to apartheid. Ecumenism in South Africa 19601987, Skotaville, Johannesburg.

Bax, D., 1997a, The Presbyterian Church of Southern Africa: An introduction, PCSA, Johannesburg.

Bax, D., 1997b, 'The Presbyterian Church of Southern Africa: Submission to the Truth and Reconciliation Commission 1997', PCSA, Johannesburg.

Bax, D., 2013, 'The struggle for justice between 1960 and 1990 and the witness of the Presbyterian Church of Southern Africa', in R. Vosloo \& M.-A. Plaatjies van Huffel
(eds.), Reformed churches in South Africa and the struggle for justice: Remembering 1960-1990, pp. 143-170, SUN Press, Stellenbosch. 
Cochrane, J., 1987, Servants of power: The role of the English-speaking churches in South Africa 1903-1930, Ravan, Johannesburg.

De Gruchy, J.W., 1979, The church struggle in South Africa, 1st edn., Eerdmans, Grand Rapids, MI.

De Gruchy, J.W. \& De Gruchy, S., 2005, The church struggle in South Africa, 25th anniversary edn., Fortress Press, Minneapolis, MN.

Denis, P. \& Duncan, G.A., 2011, The native school that caused all the trouble: A history of the Federal Theological Seminary of Southern Africa, Cluster Pietermaritzburg.

Friedman, S., 2014, 'The ambiguous legacy of Liberalism: Less a theory, more a state of mind?', in P. Vale, L. Hamilton \& E.H. Prinsloo (eds.), Intellectual traditions in South Africa: Ideas, individuals and institutions, pp. 29-50, University of KwaZuluNatal Press, Pietermaritzburg.

Heidegger, M., 1962, Being and time, transl. J. Macquarrie \& E. Robinson, Harper, New York, 1962.

Holland, N.J. s.a., 'Deconstruction', in Internet Encyclopaedia of Philosophy, viewed 09 November 2017, from http://www.iep.utm.edu/deconst/

Lennox, J., 1911, Our missions in South Africa: Missions of the United Free Church of Scotland, Foreign Mission Committee, United Free Church of Scotland, Edinburgh.

Macpherson, C.B., 1962, The political theory of possessive individualism: From Hobbes to Locke, Oxford University Press, Oxford.

Munslow, A., 2012, Deconstructing history, Institute of Historical Research, London, viewed 09 November 2017, from as-space.sas.ac.uk/4397/1/Deconstructing History_by_Alun_Munslow_Institute_of_Historical_Research.pdf

Oosthuizen, G.C., 1970, Shepherd of Lovedale. A life for Southern Africa, Keartland, Cape Town.

Presbyterian Church of South Africa (PCSA), 1898, 1900, 1975, 1979, 1982, 1990 Papers for General Assembly, PCSA, Johannesburg.
Presbyterian Church of Southern Africa (PCSA), 1957, 1962, 1963, 1964, 1965, 1966 $1969,1970,1971,1973,1979,1981,1982,1983,1984,1985,1988,1990$ Proceedings of General Assembly, PCSA, Johannesburg.

PCSA, 1960, PCSA: Book of order, PCSA, Johannesburg.

PCSA, 1971, Manual of law, practice and procedure, PCSA, Johannesburg.

PCSA, 1990, The manual of law and procedure of the Presbyterian Church of Southern Africa, PCSA, Johannesburg.

Prozesky, M. \& De Gruchy, J.W., 1995, Living faiths in South Africa, David Philip, Cape Town.

Robertson, R.J.D., 1997, The small beginning. The story of North End Presbyterian Church, East London, 1962-1970, Privately published, Cape Town.

Robertson, R.J.D., 1999, St Antony's activists, Privately printed, Cape Town.

Roux, E., 1948, Time longer than rope: A history of the black man's struggle for freedom in South Africa, Gollancz, London.

South African Native Affairs Commission (SANAC), 1903-1905 [Lagden Commission] Minutes of evidence taken in the Cape Colony, vol. II, IV, Cape Times Limited, Government Printers, Cape Town.

Stewart, J., 1894, Lovedale: South Africa, Andrew Elliot, Edinburgh. Stewart Papers, University of Cape Town Library (UCTL), BC 106:C167.

Thomson, J., 2012, Light on darkness? Missionary photography of Africa in the nineteenth and twentieth centuries, Eerdmans, Grand Rapids.

Tucker, A.R., 2012, 'Financially resourcing the ministry in the Uniting Presbyterian Church in Southern Africa in the 21st century', Verbum et Ecclesia 33(1), Art. \#695, 1-12. https://doi.org/10.4102/ve.v33i1.695

Villa-Vicencio, C., 1988, Trapped in apartheid. A socio-theological history of the English-speaking churches, David Philip, Cape Town.

Wink, W., 1987, Jesus' third way: The relevance of nonviolence in South Africa today, SACC, Johannesburg. 